International Review of Research in Open and Distributed Learning Volume 20, Number 1

February - 2019

\title{
OER Mainstreaming in Tonga
}

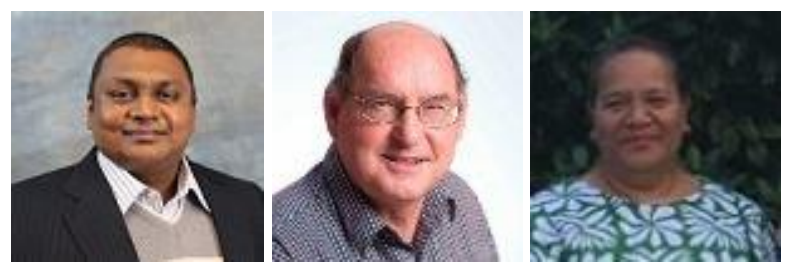

Ishan Sudeera Abeywardena', Philip Uys ${ }^{2}$, and Seilosehina Fifita ${ }^{3}$

Commonwealth of Learning ${ }^{1}$, Charles Sturt University², Tonga Institute of Higher Education ${ }^{3}$

\begin{abstract}
In the race towards achieving the Education 2030 agenda, open educational resources (OER) act as a key enabler for sustainable development goal 4 (SDG4). Leading to the 2014 Regional Focal Points Meeting, Commonwealth of Learning's (COL) Focal Point for Tonga had identified top priorities for the country where COL can further support the national agenda till 2021. Based on these needs, the Strategic OER Implementation Project in Tonga was initiated by COL in response to a request by the Ministry of Education and Training (MET) of Tonga. The project aims to assist MET in (a) developing a framework for fully utilizing the new fiber optic network infrastructure to deliver online learning to Tongans distributed in the 45 islands; and (b) improve the chances of sustainable livelihoods for Tongan youth by training them in life skills tailored to higher education and employment opportunities in Australia and New Zealand. This paper details the use of the horizontal framework for OER mainstreaming and the OER mainstreaming checklist within this project. The novelty of this project is its approach to mainstreaming OER at an institution in a systemic manner. The contribution this paper makes is to provide a proven plan for sustainable OER mainstreaming in a development setting.
\end{abstract}

Keywords: open education, open educational resources, OER, OER mainstreaming, OER mainstreaming checklist, OER policy, Tonga 


\section{Introduction}

The Kingdom of Tonga, unique among Pacific nations, never completely lost its indigenous governance. In 1845, the archipelagos of islands were united into a Polynesian kingdom, then became a constitutional monarchy in 1875, and a British protectorate in 1900. In 1970, Tonga withdrew from the protectorate and joined the Commonwealth of Nations remaining the only monarchy in the Pacific. A major political reform took place in 2010 where the King relinquished his powers and allowed the people to elect 17 representatives of the people. These representatives, in turn, select the Prime Minister. This reform was implemented in 2011 when the first Prime Minister was elected by the people.

Tonga consists of approximately 170 islands scattered across an area of the central Pacific Ocean, to the east of Fiji, although only 45 islands are inhabited (Kaitani \& McMurray, 2006). The country has a population of 106,479 with a migration rate of -17.8 migrants/10oo population (Index Mundi, 2018). Tonga's economic freedom score is 63.1 , which makes it the $76^{\text {th }}$ freest in 2018. It is also ranked $17^{\text {th }}$ among 43 countries in the Asia-Pacific region with an overall score above the regional and world averages (The Heritage Foundation, 2018). The literacy rate of Tonga, who can read or write Tongan and/or English, is $99.4 \%$ (Index Mundi, 2018).

The Commonwealth of Learning (COL) is an intergovernmental organization created by Commonwealth Heads of Government to promote the development and sharing of open learning and distance education knowledge, resources, and technologies. Hosted by the Government of Canada and headquartered in Burnaby, British Columbia, Canada, COL is the world's only intergovernmental organization solely concerned with the promotion and development of distance education and open learning. COL actively helps developing nations improve access to quality education and training (Commonwealth of Learning, 2018).

In the lead-up to the 2014 Regional Focal Points Meeting, COL's Focal Point for Tonga had identified top priorities for the country where COL can further support the national agenda until 2021 (Commonwealth of Learning, 2015). As a follow-up, COL, through the Open Educational Resources for Skills Development (OER for SD) project, looked to focus on the areas of: (a) training teachers to develop online materials at higher education levels; (b) building capacity to upskill teachers in using information and communication technologies (ICTs) in teaching and learning; and (c) establishing new physical infrastructure in the Tonga Institute of Higher Education (TIHE) and the Tonga Institute of Education (TIOE).

The TIHE is a tertiary education branch of the Ministry of Education and Training (MET) of Tonga. Its umbrella spans several programs that focus on educating students in a variety of professional aptitudes and vocations (The Tonga Institute of Higher Education, 2018). TIOE strives to provide relevant teacher education programs to contribute to producing Tongan teachers who will meet the needs and expectations of its stakeholders (Ministry of Education and Training, 2017). Based on the priorities identified, this paper details the mainstreaming of open educational resources (OER) at the TIHE and TIOE under Phase 1 and Phase 2 of the Strategic OER Implementation Project in Tonga. The novelty of this project is its approach to mainstreaming OER at an institution in a systemic manner. The contribution this paper makes is to provide a proven plan for sustainable OER mainstreaming in a development setting. 


\section{Methodology}

In the race towards achieving the Education 2030 agenda (UNESCO, 2015), OER act as a key enabler for sustainable development goal 4 (SDG4). The Ljubljana Action Plan defines OER as:

Toward the realization of inclusive Knowledge Societies, Open Educational Resources (OER) support quality education that is equitable, inclusive, open and participatory. OER are teaching, learning and research materials in any medium - digital or otherwise - that reside in the public domain or have been released under an open license that permits no-cost access, use, adaptation and redistribution by others with no or limited restrictions. Open licensing is built within the framework of intellectual property rights as defined by relevant international conventions to respect the authorship of work. OER are a strategic opportunity to improve knowledge sharing, capacity building and universal access to quality learning and teaching resources. (UNESCO, 2017, p. 1).

In 2016, COL's Kuala Lumpur Declaration (Commonwealth of Learning, 2016a) recommends the mainstreaming of OER use by developing strategies and policies at governmental and institutional levels to enhance quality while potentially reducing the cost of education. However, in 2017, the Ljubljana Action Plan identifies five main challenges to mainstreaming OER which are: (a) the capacity of users to find, reuse, create, and share OER; (b) language and cultural issues; (c) ensuring inclusive and equitable access to quality OER; (d) changing sustainability models; and (e) developing supportive policy environments. In response, COL recommends several concrete actions to mainstream OER (Commonwealth of Learning, 2017) which are: (a) develop and implement an institutional OER policy; (b) create institutional mechanisms for OER quality assurance; (c) recognize faculty contribution to OER; (d) institute an award for best OER; (e) create an institutional repository for OER; (f) regularly organize capacity-building programs for teachers; (g) conduct and support research on OER; (h) collaborate with other institutions to avoid reinventing the wheel; (i) take steps to improve the institution's ICT infrastructure; and (j) develop accessible OER. To guide the implementation of these recommendations in a practical scenario, Abeywardena (2017) proposes the horizontal framework for OER mainstreaming (Figure 1) and the OER mainstreaming checklist (Table 1). The methodology of this project is based on this framework and checklist proposed by Abeywardena. 


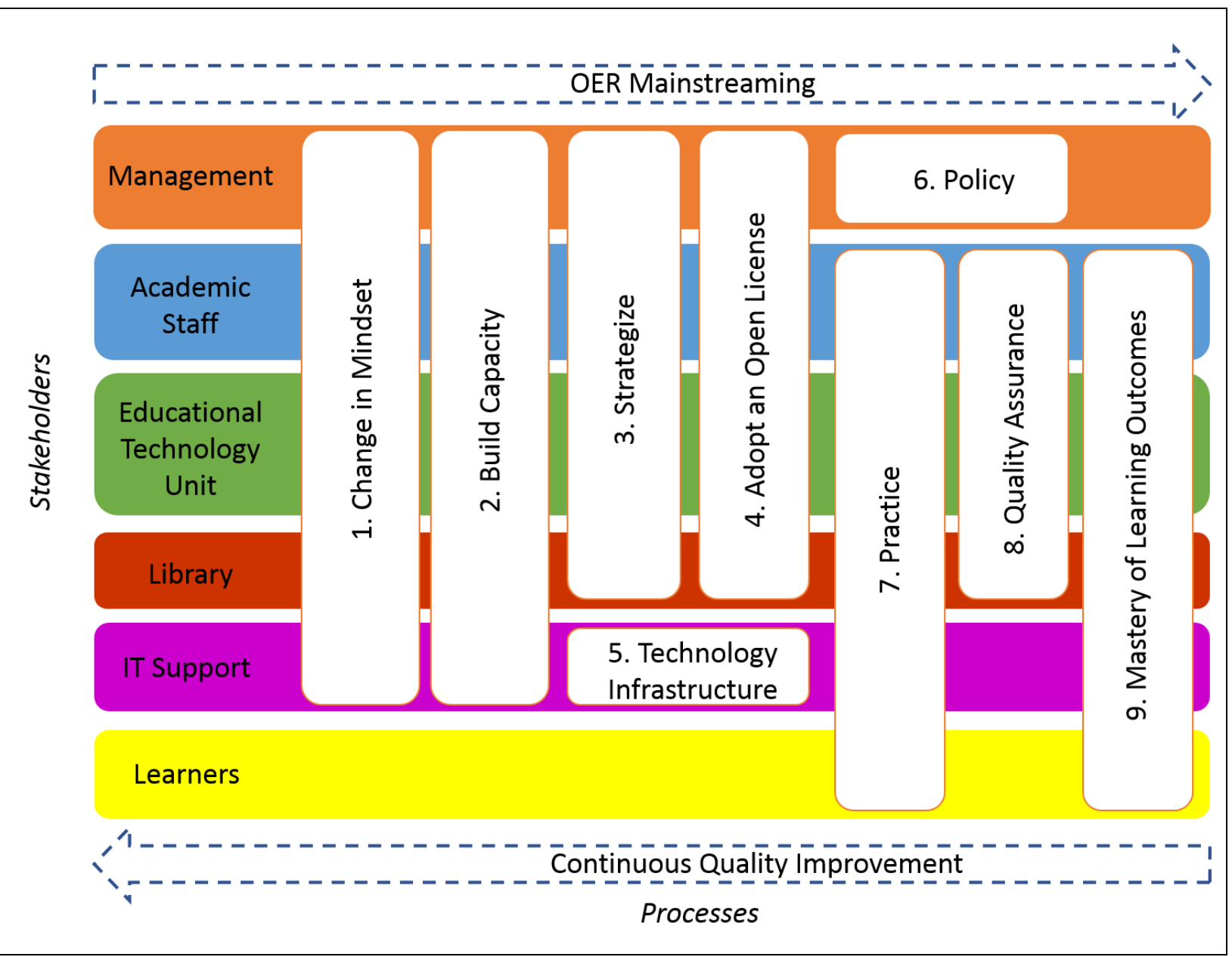

Figure 1. Horizontal framework for OER mainstreaming in an institution. Adapted from "An empirical framework for mainstreaming OER in an academic institution," by I.S. Abeywardena, 2017, Asian Association of Open Universities Journal, 12(2), p. 232. CC BY 4.0.

Table 1

OER Mainstreaming Checklist

\begin{tabular}{|c|c|c|c|c|c|c|c|}
\hline \multirow[b]{2}{*}{ Process } & \multicolumn{6}{|c|}{ Stakeholder } & \multirow[b]{2}{*}{ Mainstreaming tasks } \\
\hline & 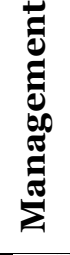 & 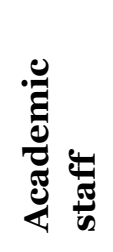 & 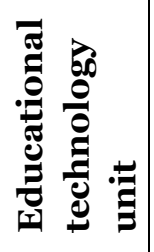 & 苞 & 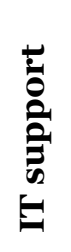 & 递 & \\
\hline $\begin{array}{l}\text { 1. Change in } \\
\text { mindset }\end{array}$ & $\sqrt{ }$ & $\checkmark$ & $\checkmark$ & $\sqrt{ }$ & $\sqrt{ }$ & & $\begin{array}{l}\text { 1.1 Decided to reuse and produce OER? } \\
\text { 1.2 Changed mindsets: Open is Good? }\end{array}$ \\
\hline
\end{tabular}




\begin{tabular}{|c|c|c|c|c|c|c|c|}
\hline 2. Build capacity & $\sqrt{ }$ & & & $\sqrt{ }$ & $\sqrt{ }$ & & $\begin{array}{l}\text { 2.1 What are OER? } \\
\text { 2.2 What are the types of OER? } \\
\text { 2.3 What is open and accessible? } \\
\text { 2.4 What is copyright and open licensing? } \\
\text { 2.5 How to create, reuse, revise, and remix } \\
\text { OER using FOSS? }\end{array}$ \\
\hline 3. Strategize & $\sqrt{ }$ & & & $\sqrt{ }$ & & & $\begin{array}{l}\text { 3.1 Identified the need for OER in terms of } \\
\text { cost, quality and access? } \\
\text { 3.2 Identified short, medium and long-term } \\
\text { goals for OER? } \\
\text { 3.3 Identified representatives from each } \\
\text { stakeholder group for task teams? }\end{array}$ \\
\hline $\begin{array}{ll}\text { 4. } & \text { Adopt an open } \\
\text { license }\end{array}$ & $\checkmark$ & & & $\sqrt{ }$ & & & $\begin{array}{l}\text { 4.1 How open is the institution? } \\
\text { 4.2 How open are current materials? } \\
\text { 4.3 Allow commercial use? } \\
\text { 4.4 Enforce Share-Alike? } \\
\text { 4.5 Allow derivatives? } \\
\text { 4.6 No Rights Reserved? }\end{array}$ \\
\hline $\begin{array}{ll}5 \cdot & \text { Technology } \\
& \text { infrastructure }\end{array}$ & & & & & $\sqrt{ }$ & & $\begin{array}{l}\text { 5.1 Have sufficient technology infrastructure? } \\
5.2 \text { Have sufficient technical personnel? } \\
\text { 5.3 Invest in cloud based technologies and } \\
\text { services? } \\
\text { 5.4 Setup a FOSS repository? }\end{array}$ \\
\hline 6. Policy & $\sqrt{ }$ & & & & & & $\begin{array}{l}\text { 6.1 Adopted an Institutional OER policy? } \\
\text { 6.2 Updated HR policies to recognize and } \\
\text { reward OER activities? } \\
\text { 6.3 Recognize additional work in OER? } \\
\text { 6.4 Made OER a Key Performance Indicator } \\
\text { (KPI)? } \\
\text { 6.5 Developed a system for remuneration and } \\
\text { encouragement? } \\
\text { 6.6 Mainstreamed open educational } \\
\text { practices? }\end{array}$ \\
\hline 7. Practice & & & & $\sqrt{ }$ & & $\sqrt{ }$ & $\begin{array}{l}\text { 7.1 Which courses to make OER? } \\
\text { 7.2 Developed a systematic approach to OER } \\
\text { content development? } \\
\text { 7.3 Formed course development teams? } \\
\text { 7.4 Identified useful OER for course } \\
\text { development? } \\
\text { 7.5 Developed/adapted course successfully? } \\
\text { 7.6 Developed pilot OER? } \\
\text { 7.7 Added metadata and built a catalogue? }\end{array}$ \\
\hline $\begin{array}{ll}\text { 8. } & \text { Quality } \\
& \text { assurance (QA) }\end{array}$ & & $\sqrt{ }$ & $\sqrt{ }$ & $\sqrt{ }$ & & & $\begin{array}{l}\text { 8.1 Formed an OER QA Team? } \\
\text { 8.2 Is this content suitable for our learners? } \\
\text { 8.3 Is it pedagogically sound? } \\
\text { 8.4 Is it open and accessible? } \\
\text { 8.5 Do we have tech support? }\end{array}$ \\
\hline
\end{tabular}




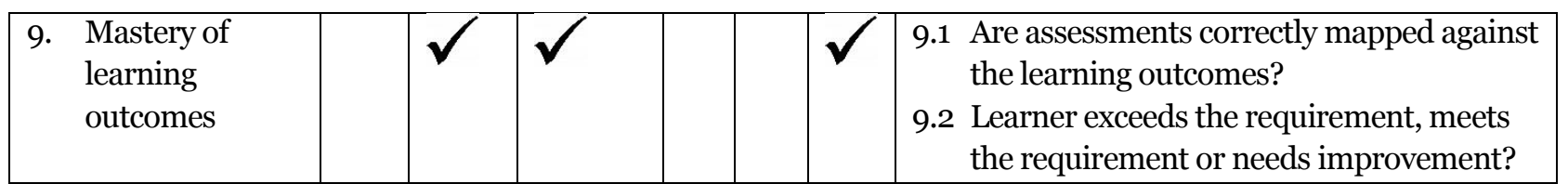

Note. Adapted from "An empirical framework for mainstreaming OER in an academic institution," by I.S. Abeywardena, 2017, Asian Association of Open Universities Journal, 12(2), p. 233. CC BY 4.o.

The Strategic OER Implementation Project in Tonga is a two-year long intervention by COL in response to a request by the MET of Tonga. The four phases of the project (Figure 2) aim to assist MET (a) to develop a framework for fully utilizing the new fiber optic network infrastructure enabling the delivery of online learning to Tongans distributed in the 45 islands; and (b) to improve the chances of sustainable livelihoods for Tongan youth by training them in life skills tailored to higher education and employment opportunities in Australia and New Zealand.

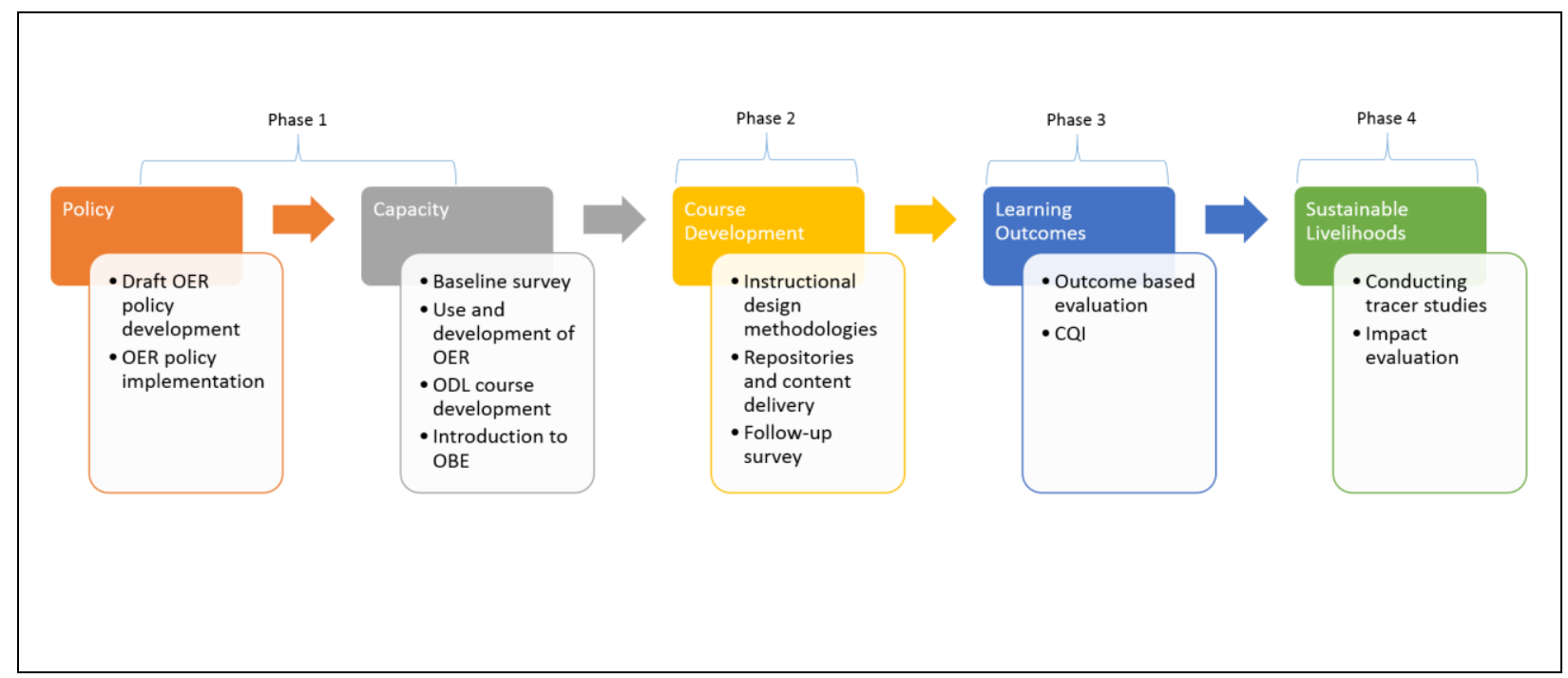

Figure 2. Project flowchart for the strategic OER implementation project in Tonga.

The activities, outputs and expected outcomes of the project are summarized in the project evaluation chart (Table 2). The various stages of the project model that correspond to the key stakeholders are detailed in Figure 3 . 


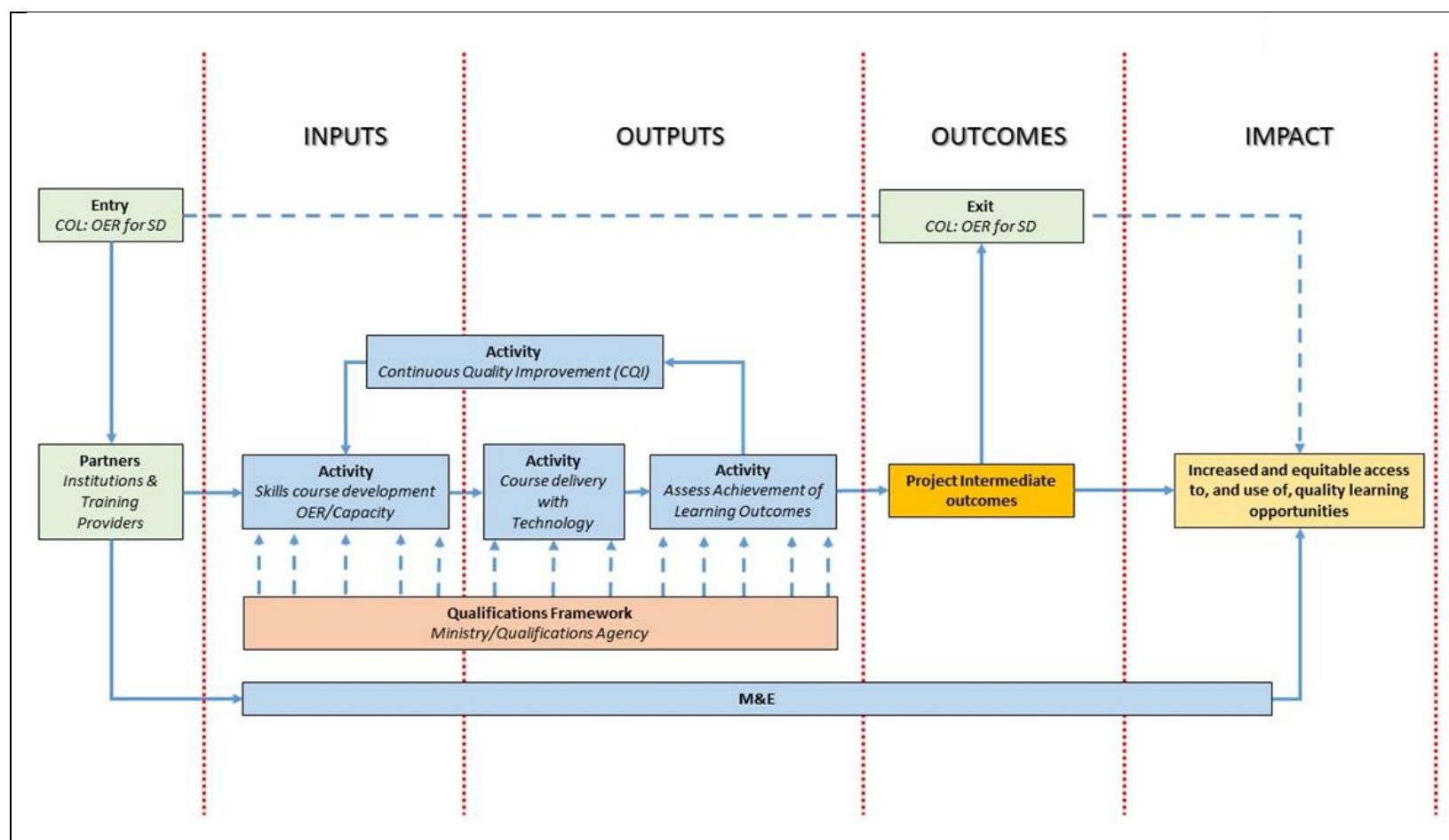

Figure 3. OER for skills development project model.

Table 2

Project Evaluation Chart for the Strategic OER Implementation Project in Tonga

\begin{tabular}{|c|c|c|c|c|c|}
\hline $\begin{array}{l}\text { Project } \\
\text { phase }\end{array}$ & Outcome & Activity & $\begin{array}{l}\text { Indicator and data } \\
\text { source }\end{array}$ & Baseline & Target \\
\hline \multirow{2}{*}{$\begin{array}{l}\text { Phase } 1 \\
\text { (Feb - Jun, } \\
\text { 2017) }\end{array}$} & $\begin{array}{l}\text { Outcome \#1: } \\
\text { Strategic } \\
\text { implementation of } \\
\text { OER practices at } \\
\text { TIOE and TIHE } \\
\text { through } \\
\text { Institutional OER } \\
\text { policies under the } \\
\text { purview of the MET. }\end{array}$ & $\begin{array}{l}\text { Consultation, } \\
\text { advocacy and } \\
\text { capacity building } \\
\text { for policymakers } \\
\text { to develop and } \\
\text { implement OER } \\
\text { policy frameworks. }\end{array}$ & $\begin{array}{c}\text { Number of institutional } \\
\text { OER policies developed } \\
\text { - Data source: } \\
\text { institutional } \\
\text { documents. }\end{array}$ & 0 & $\begin{array}{l}2 \text { (or one } \\
\text { national } \\
\text { policy } \\
\text { depending } \\
\text { on } \\
\text { protocol). }\end{array}$ \\
\hline & $\begin{array}{l}\text { Outcome \#2: } \\
\text { TIOE and TIHE } \\
\text { integrate OER in } \\
\text { teaching and } \\
\text { learning effectively. }\end{array}$ & $\begin{array}{l}\text { Capacity building } \\
\text { in use and } \\
\text { development of } \\
\text { OER in teaching } \\
\text { and learning. }\end{array}$ & $\begin{array}{l}\text { Percentage of teachers } \\
\text { who use and develop OER } \\
\text { for teaching and learning } \\
\text { - Data source: } \\
\text { baseline survey, } \\
\text { follow-up surveys } \\
\text { and portfolio } \\
\text { evidence. }\end{array}$ & $<5 \%$ & $25 \%$ \\
\hline
\end{tabular}




\begin{tabular}{|c|c|c|c|c|c|}
\hline $\begin{array}{l}\text { Phase } 2 \\
\text { (Jun - Dec, } \\
\text { 2017) }\end{array}$ & $\begin{array}{l}\text { Outcome \#3: } \\
\text { TIOE and TIHE } \\
\text { develop good } \\
\text { quality learning } \\
\text { materials and share } \\
\text { as OER. }\end{array}$ & $\begin{array}{l}\text { Support OER } \\
\text { course } \\
\text { development. }\end{array}$ & $\begin{array}{l}\text { Number of courses } \\
\text { developed using OER and } \\
\text { as OER } \\
\text { - } \\
\quad \text { Data source: } \\
\text { course materials } \\
\text { available on } \\
\text { institutional/COL } \\
\text { repositories and } \\
\text { portfolio evidence. }\end{array}$ & O & 4 \\
\hline $\begin{array}{l}\text { Phase } 3 \\
\text { (Jan - Jun, } \\
\text { 2018) }\end{array}$ & $\begin{array}{l}\text { Outcome \#4: } \\
\text { Satisfactory } \\
\text { achievement of } \\
\text { course learning } \\
\text { outcomes by } \\
\text { learners viz. the } \\
\text { OER courses } \\
\text { developed. }\end{array}$ & $\begin{array}{l}\text { Support } \\
\text { implementation of } \\
\text { outcome based } \\
\text { education (OBE), } \\
\text { outcomes based } \\
\text { evaluation and } \\
\text { continuous quality } \\
\text { improvement } \\
\text { (CQI) strategies. }\end{array}$ & $\begin{array}{l}\text { Percentage of learners who } \\
\text { achieve } 50 \% \text { or higher of } \\
\text { the course learning } \\
\text { outcomes. } \\
\text { - Data source: } \\
\text { summative and } \\
\text { formative } \\
\text { assessment results } \\
\text { of learners. }\end{array}$ & unknown & $80 \%$ \\
\hline $\begin{array}{l}\text { Phase } 4 \\
\text { (Jun, } 2018 \\
\text { - Jun, } \\
\text { 2019) }\end{array}$ & $\begin{array}{l}\text { Outcome \#5: } \\
\text { Improved } \\
\text { sustainable } \\
\text { livelihoods. }\end{array}$ & $\begin{array}{l}\text { Support tracer } \\
\text { studies to } \\
\text { approximate the } \\
\text { impact of OER. }\end{array}$ & $\begin{array}{l}\text { Number of learners who } \\
\text { have been exposed to OER } \\
\text { and have been able to } \\
\text { achieve sustainable } \\
\text { livelihoods. } \\
\text { - Data source: } \\
\text { tracer study } \\
\text { results. }\end{array}$ & unknown & 200 \\
\hline
\end{tabular}

\section{Results}

Following an official visit to Tonga by the Vice President of COL in September 2016, a few key areas were identified where COL could assist the MET. This included: (a) building capacity in OER and developing OER based courses; (b) supporting MET in developing a policy framework for OER; and (c) strengthening online learning with a focus on the Moodle learning management system (LMS). To address these needs in a structured and holistic manner which will ensure medium-term impact and sustainability, COL and the MET entered into a contribution agreement in January 2017 under the Strategic OER Implementation Project in Tonga (Table 2). Phase 1 of the project, which took place from February to June 2017, saw the drafting of a national OER policy and capacity building in OER reuse in course design. Phase 2 of the project, from June to December 2017, focused on the development and online delivery of four pilot OER courses in the field of life skills.

\section{Phase 1}

Consultation, advocacy, and capacity building for policymakers to develop and implement OER policy frameworks. In collaboration with policymakers of the MET, TIHE, and TIOE, strengthened by legal staff at the MET, COL supported the development of a draft national OER policy for 
government higher education institutions of Tonga based on COL's Institutional OER Policy Template (Commonwealth of Learning, 2016b). The draft policy is currently under review by the MET for adoption.

Capacity building in use and development of OER in teaching and learning. A five-day intensive hands-on capacity building workshop was conducted by a COL expert in June 2017 with the participation of 34 full time academic staff, including some members of the senior management, from TIOE and TIHE. The workshop program was developed to address the major skills gaps identified in the Open Educational Resources in the Commonwealth 2016 report (Phalachandra \& Abeywardena, 2016), which include: (a) teachers' use of OER; (b) perceptions of OER; (c) reuse, revision, remixing, and redistribution; (d) challenges of using OER; (e) adopting and sharing materials; and (f) locating and retrieving OER. The key outputs of the workshop are: (a) identifying specific need for OER at the two institutions; (b) capacity building in the use of OER in course development; (c) training in instructional video production for online courses and MOOC; (d) skills development in the use of free and open source software (FOSS) in repurposing multiple OER formats; (e) introduction to the Moodle LMS; and (f) training in the use of COL's course development resources such as the course blueprint template, course development template, and the external course evaluation toolkit (Smulders, 2016). Based on a follow-up survey of the participants $(n=26)$, only four participants $(15 \cdot 38 \%)$ hadn't used OER since undergoing training (Figure 4$)$.

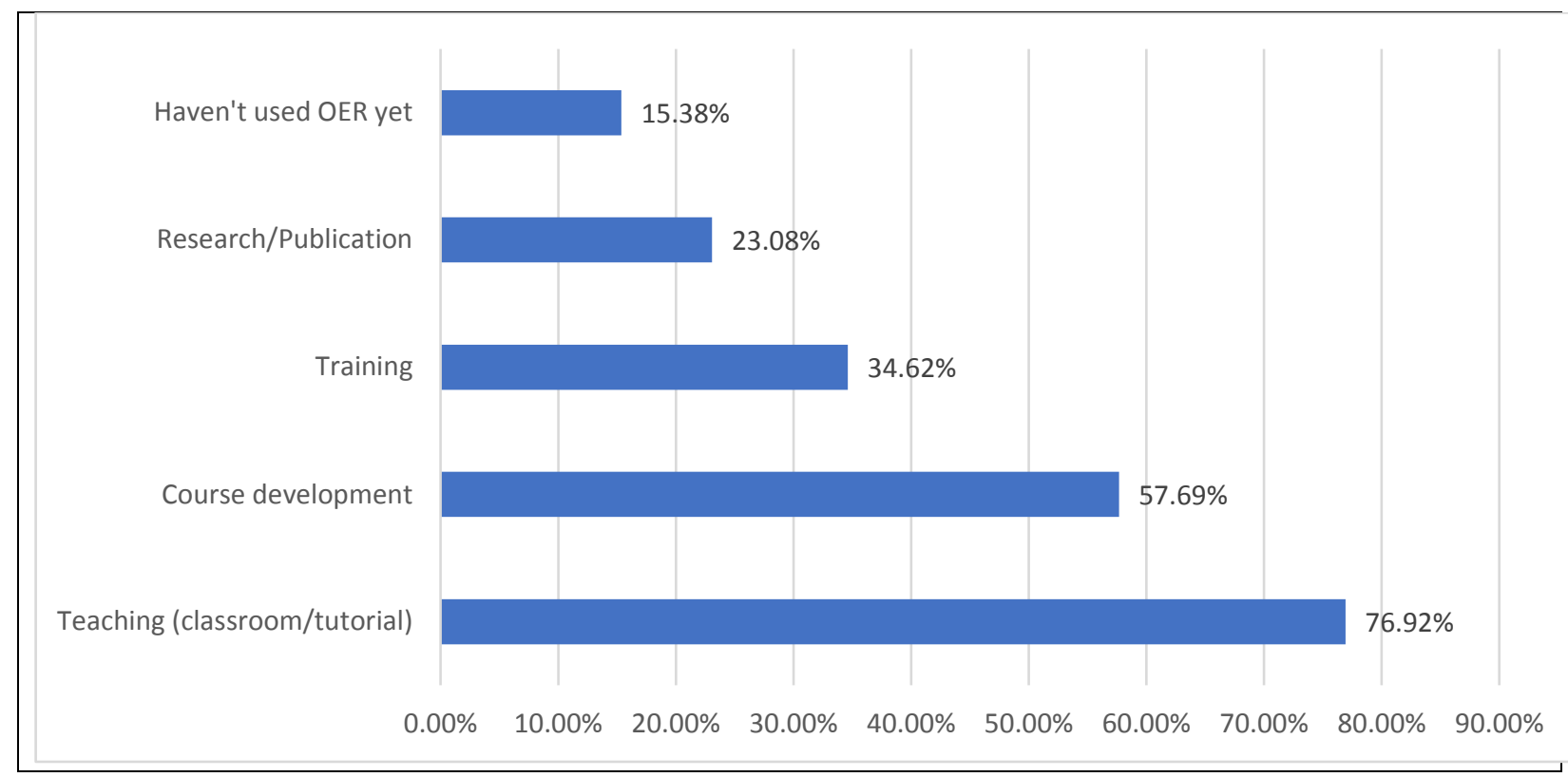

Figure 4. Results of follow-up survey on OER use.

Further, the workshop was used as a successful field test of the 12-part video course on Instructional Video Production for Teaching and Learning (The Open University of Sri Lanka, 2017) and the Creating and Repurposing OER Using FOSS: A How-To Guide for Teachers and Learners (Kasinathan \& Ranganathan, 2017). The participants followed the course on video production to plan, script, and shoot instructional videos on various topics. Then they used the toolkit on repurposing OER using FOSS to edit sound and video resulting in 5-10 minute instructional video clips. The creation of these videos was done from start to finish over two afternoon sessions. These sessions resulted in upskilling the teachers to develop more video based material on their own using accessible technologies such as smart phones and FOSS. The participants 
said that they felt "surprised and empowered by the new skills they have gained" and would utilize the medium of video more in their content delivery.

\section{Phase 2}

Support OER course development. Further to the aims of the project stated in the methodology section, four pilot courses on life skills were proposed to be developed and delivered online using the Moodle LMS. The courses TIHE WS2Oo Working and Social Skills and TIHE TL1Oo Thinking and Learning Skills have been offered in the first semester of 2018 whereas TIOE ITT1O1 Information Technology and TIOE RP1O1 Restorative Practices will be offered in the second semester of 2018.

The course development process was approached in three inter-related stages. First, four independent teams were formed with 4-6 teachers each tasked with completing the course development. The teams engaged with a COL expert through an online forum for 14 days to finalize the course blueprints and compile available OER, such as video clips and case studies, to be used in the courses. Second, a hands-on workshop was conducted in November 2017 for TIHE and TIOE staff (held at the TIHE) facilitated by the COL expert. This workshop aimed to develop participants' skills in online course design and development, delivering online courses using Moodle, and reusing/remixing OER. In addition to the course development team members, staff from the library, educational technology unit, and IT support services participated in several focused sessions which were designed to help them support online delivery. Using the course blueprints as inputs, the participants worked in teams to develop the courses, on institutional Moodle platforms supported by COL, in real-time. It was unrealistic to expect the courses to be $100 \%$ completed during the workshop due to the short time frame; however, the course development teams managed to complete approximately $70 \%$ of the development within the duration of the workshop. Subsequently, the course development teams continued to complete the courses with virtual support from the COL expert. The courses TIHE WS2OO Working and Social Skills and TIHE TL1Oo Thinking and Learning Skills are currently being offered in the first semester of 2018 by the TIHE to 139 and 137 learners respectively.

\section{Discussion}

The evaluation of this project is twofold. First, the outcomes of the project are evaluated based on the project evaluation chart (Table 2). To elaborate: outcome \#1 - strategic implementation of OER practices at TIOE and TIHE through Institutional OER policies under the purview of the MET has been achieved through the development of a national OER policy draft aimed at government higher education institutions; outcome \#2 - TIOE and TIHE integrate OER in teaching and learning effectively has been achieved through $84 \%$ of the participants using OER in some form in their teaching. Further, cascading training has taken place in TIHE and TIOE to build capacity of temporary teaching staff; and outcome \# 3 - TIOE and TIHE develop good quality learning materials and share as OER has been achieved through the development of four OER based life skills courses. By evaluating the targets set in Table 2 against the results, we consider the outcomes of Phase 1 and Phase 2 of this project to be successfully achieved.

Second, the methodology for this project is structured around the horizontal framework for OER mainstreaming in an institution (Figure 1) and the OER mainstreaming checklist (Table 1). According to 
Abeywardena (2017), each process in the OER mainstreaming checklist vis-à-vis the mainstreaming tasks, need to be completed for the successful mainstreaming of OER in an institution. Table 3 summarizes the outputs of Phase 1 and 2 of the project against the mainstreaming checklist.

Table 3

Summary of Project Outputs from Phase 1 and Phase 2 Against the Mainstreaming Checklist

\begin{tabular}{|c|c|c|}
\hline Process & Mainstreaming tasks & Project outputs \\
\hline $\begin{array}{l}\text { 1. Change in } \\
\text { mindset }\end{array}$ & $\begin{array}{l}\text { 1.1 Decided to reuse and } \\
\text { produce OER? } \\
\text { 1.2 Changed mindsets: } \\
\text { Open is Good? }\end{array}$ & $\begin{array}{l}\text { Following an official visit to Tonga by the Vice } \\
\text { President of COL in September 2016, a few key areas } \\
\text { were identified where COL could assist the MET } \\
\text { which included: (a) building capacity in OER and } \\
\text { developing OER based courses; (b) supporting MET } \\
\text { in developing a policy framework for OER; and (c) } \\
\text { strengthening online learning with a focus on the } \\
\text { Moodle LMS. }\end{array}$ \\
\hline Build capacity & $\begin{array}{l}\text { 2.1 What are OER? } \\
\text { 2.2 What are the types of } \\
\text { OER? } \\
\text { 2.3 What is open and } \\
\text { accessible? } \\
\text { 2.4 What is copyright and } \\
\text { open licensing? } \\
\text { 2.5 How to create, reuse, } \\
\text { revise, and remix OER } \\
\text { using FOSS? }\end{array}$ & $\begin{array}{l}\text { The hands-on capacity building workshop conducted } \\
\text { in Phase } 1 \text { covered many OER related topics, which } \\
\text { include understanding OER licensing requirements; } \\
\text { understanding the need for OER in course design; } \\
\text { converting a resource to OER and redistributing; } \\
\text { evaluating and choosing suitable OER; introduction } \\
\text { to oerfaq.info community of practice; OER search; } \\
\text { applying OER concepts in course design; practical } \\
\text { challenges of reusing OER in course design; FOSS } \\
\text { tools for OER reuse/remix; and OER repositories and } \\
\text { search. }\end{array}$ \\
\hline 3 Strategize & $\begin{array}{l}\text { 3.1 Identified the need for } \\
\text { OER in terms of cost, } \\
\text { quality and access? } \\
\text { 3.2 Identified short, } \\
\text { medium and long- } \\
\text { term goals for OER? }\end{array}$ & $\begin{array}{l}\text { The aims of the project were set (a) to develop a } \\
\text { framework for fully utilizing the new fiber optic } \\
\text { network infrastructure enabling the delivery of online } \\
\text { learning to Tongans distributed in the } 45 \text { islands; and } \\
\text { (b) to improve the chances of sustainable livelihoods } \\
\text { for Tongan youth by training them in life skills } \\
\text { tailored to higher education and employment } \\
\text { opportunities in Australia and New Zealand. In the } \\
\text { short-term, four pilot OER courses on life skills were } \\
\text { proposed to be developed and delivered online using } \\
\text { the Moodle LMS. In the medium-term, the project } \\
\text { builds capacity of staff to develop and deliver OER } \\
\text { based courses online. In the long-term, the use of } \\
\text { OER and online delivery improves access to } \\
\text { education for Tongans and leads to sustainable } \\
\text { livelihoods. } \\
\text { Representatives from academic staff, IT support, } \\
\text { educational technology unit, library, and } \\
\text { management participated in phase } 1 \text { and phase } 2 \text { of }\end{array}$ \\
\hline
\end{tabular}




\begin{tabular}{|c|c|c|c|}
\hline & & $\begin{array}{l}\text { each stakeholder } \\
\text { group for task teams? }\end{array}$ & $\begin{array}{l}\text { the project. Learners will be involved in phase } 3 \text { and } \\
\text { phase } 4 .\end{array}$ \\
\hline $\begin{array}{l}\text { Adopt an open } \\
\text { license }\end{array}$ & $\begin{array}{l}4.1 \\
4.2 \\
4.3 \\
4.4 \\
4.5 \\
4.6\end{array}$ & $\begin{array}{l}\text { How open is the } \\
\text { institution? } \\
\text { How open are current } \\
\text { materials? } \\
\text { Allow commercial use? } \\
\text { Enforce Share-Alike? } \\
\text { Allow derivatives? } \\
\text { No Rights Reserved? }\end{array}$ & $\begin{array}{l}\text { The draft national OER policy for government higher } \\
\text { education institutions of Tonga (see policy section for } \\
\text { more details) addresses all related issues under the } \\
\text { "copyright and licenses" section, which include } \\
\text { ownership of content, access to available content, } \\
\text { sharing of intellectual property, license used for all } \\
\text { materials developed, responsibility of authors and } \\
\text { content creators, declarations, and caveats. }\end{array}$ \\
\hline $\begin{array}{ll}5 & \text { Technology } \\
& \text { infrastructure }\end{array}$ & 5.2 & $\begin{array}{l}\text { Invest in cloud based } \\
\text { technologies and } \\
\text { services? } \\
\text { Setup a FOSS } \\
\text { repository? }\end{array}$ & $\begin{array}{l}\text { The technology infrastructure at the TIHE and TIOE } \\
\text { is at its infancy. However, the project has prompted } \\
\text { the need for upgrading the infrastructure and } \\
\text { budgetary allocations for new infrastructure } \\
\text { development based on future requirements. } \\
\text { IT support staff are available for basic day-to-day } \\
\text { support. However, they had limited expertise and } \\
\text { resources in terms of setup and support of the } \\
\text { Moodle LMS. As an interim arrangement, Moodle } \\
\text { support is provided by COL for a duration of two } \\
\text { years until the infrastructure is put in place and the } \\
\text { staff trained. } \\
\text { The MET is exploring the use of Moodle Cloud as a } \\
\text { long-term solution. } \\
\text { The setup of an OER repository hasn't been discussed } \\
\text { yet due to the lack of infrastructure and technical } \\
\text { support. }\end{array}$ \\
\hline $\begin{array}{ll}6 & \text { Policy }\end{array}$ & $\begin{array}{l}6.1 \\
6.2 \\
6.3 \\
6.4 \\
6.5 \\
6.6\end{array}$ & $\begin{array}{l}\text { Adopted an } \\
\text { Institutional OER } \\
\text { policy? } \\
\text { Updated HR policies } \\
\text { to recognize and } \\
\text { reward OER activities? } \\
\text { Recognize additional } \\
\text { work in OER? } \\
\text { Made OER a Key } \\
\text { Performance Indicator } \\
\text { (KPI)? } \\
\text { Developed a system for } \\
\text { remuneration and } \\
\text { encouragement? } \\
\text { Mainstreamed open } \\
\text { educational practices? }\end{array}$ & $\begin{array}{l}\text { In collaboration with policymakers of the MET, } \\
\text { TIHE, and TIOE, strengthened by legal staff at the } \\
\text { MET, COL supported the development of a draft } \\
\text { national OER policy for government higher } \\
\text { education institutions of Tonga based on COL's } \\
\text { Institutional OER Policy Template. The statements of } \\
\text { this policy include purpose, scope, and applicability; } \\
\text { OER definitions; objectives; copyright and licenses; } \\
\text { quality assurance and review system; liability; } \\
\text { institutional arrangements; implementation strategy; } \\
\text { monitoring and evaluation; and legislative } \\
\text { compliance. These statements address all the } \\
\text { mainstreaming tasks under policy. The draft policy is } \\
\text { currently under review by the MET for adoption. }\end{array}$ \\
\hline
\end{tabular}




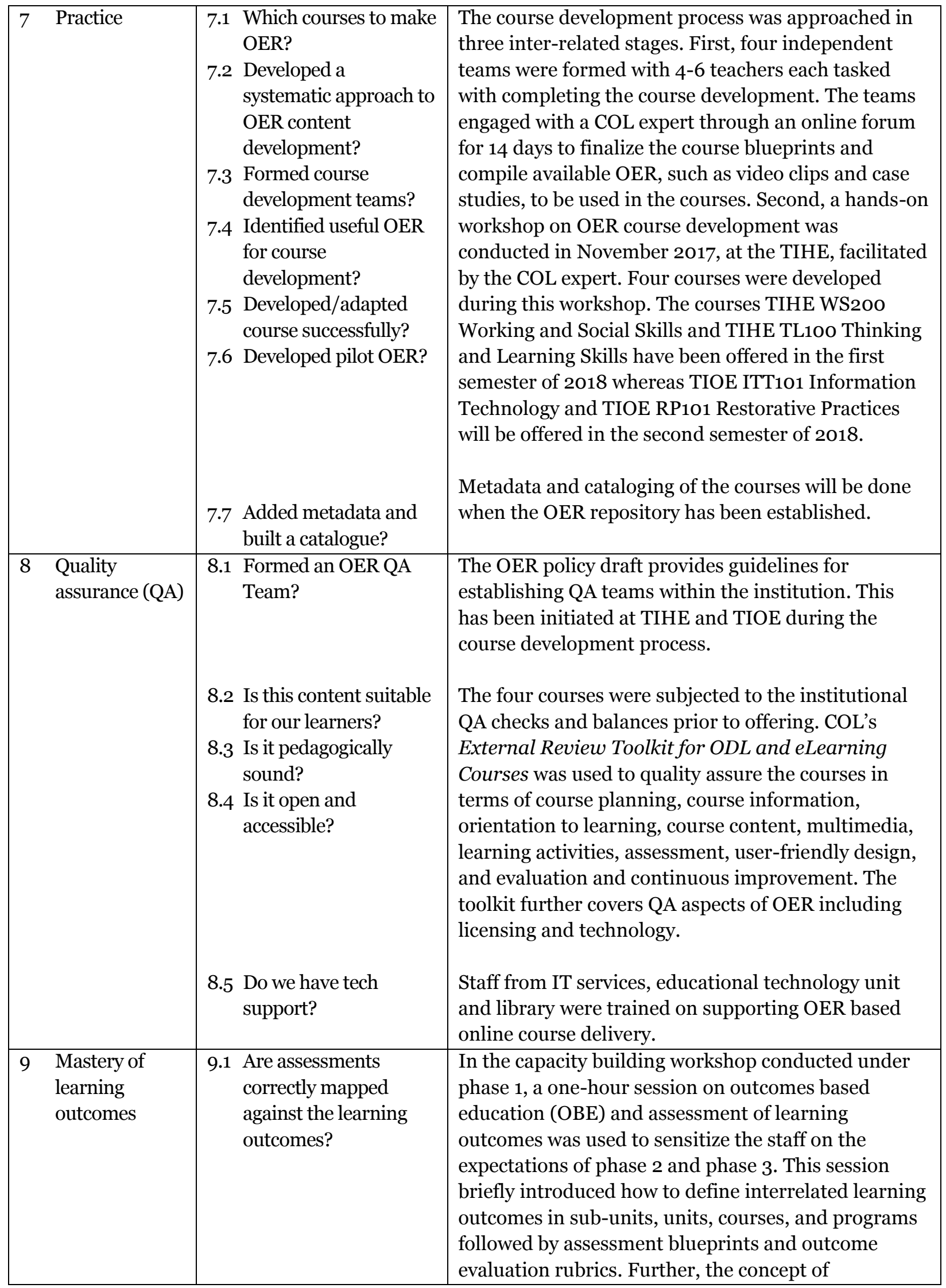




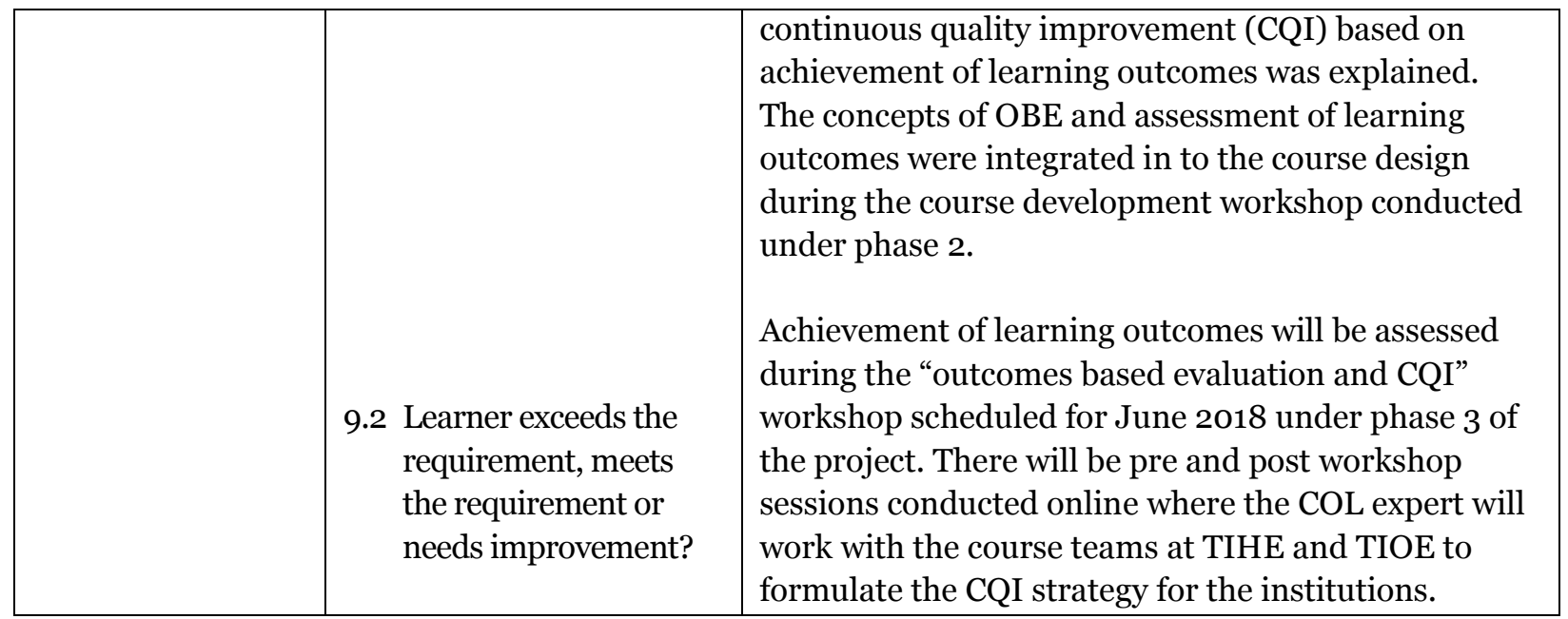

Based on the project outputs summarized in Table 3, we believe that almost all mainstreaming tasks have been addressed during phase 1 and phase 2 of the project. Once phase 3 is complete, we believe that OER will be successfully mainstreamed at the TIHE and TIOE in a sustainable manner. When the two institutions achieve sustainability, COL will exit the partnership as shown in Figure 3.

Among the challenges faced during the course development process, limited computer skills and subject matter expertise were prominent. These challenges were addressed through increased guidance and contact time from the COL expert. In terms of Moodle, the COL appointed administrator worked closely with the course development teams to setup the platform to suit their teaching needs. However, there were initial delays due to the lack of experience by teaching staff in the use of the LMS. These delays were soon addressed by establishing procedures for communication, requests, and turnaround times.

\section{Conclusion}

In 2017, the Ljubljana Action Plan identifies five main challenges to mainstreaming OER. In response, the Commonwealth of Learning (COL) recommends several concrete actions to mainstream OER. To guide the implementation of these recommendations in a practical scenario, Abeywardena (2017) proposes the horizontal framework for OER mainstreaming and the OER mainstreaming checklist. This paper details the use of the horizontal framework for OER mainstreaming and the OER mainstreaming checklist within the Strategic OER Implementation Project in Tonga. By evaluating the targets of the project against the results and by addressing almost all the mainstreaming tasks outlined in the OER mainstreaming checklist, we consider the outcomes of Phase 1 and Phase 2 of this project to be successfully achieved. The novelty of this project is its approach to mainstreaming OER at an institution in a systemic manner. The contribution this paper makes is to provide a proven plan for sustainable OER mainstreaming in a development setting.

The discussion details the findings of phase 1 and phase 2 of the project. Overall the horizontal framework for OER mainstreaming and the OER mainstreaming checklist have been proven to deliver on their aims 
and can be used by other educational institutions in developing countries to mainstream OER. Phase 3 of the project will concentrate on evaluating the mastery of learning outcomes and continuous quality improvement. Phase 4 of the project will draw conclusions on the impact of OER mainstreaming on improved sustainable livelihoods in Tonga.

\section{Acknowledgements}

This project was funded as part of the Grant \#2015-2585 generously made by The William and Flora Hewlett Foundation, USA.

The authors acknowledge the support of The Ministry of Education and Training, Tonga; Mr Claude Tupou; Madam Siatukimoana Vaea; Ms Liuaki Fusitu'a; Mr Sofilisi Hingano; and Mrs ‘Ana Lupe Voi. 


\section{References}

Abeywardena, I. S. (2017). An empirical framework for mainstreaming OER in an academic institution. Asian Association of Open Universities Journal, 12(2), 230-242.

Commonwealth of Learning. (2015). Tonga 2012-2015: Country report. Burnaby: COL. Retrieved from http://hdl.handle.net/11599/995

Commonwealth of Learning. (2016a). 2016 Kuala Lumpur declaration. Kuala Lumpur: 8th PanCommonwealth Forum. Retrieved from http://hdl.handle.net/11599/2661

Commonwealth of Learning. (2016b). Institutional OER policy template. Burnaby: COL. Retrieved from http://oasis.col.org/handle/11599/2361

Commonwealth of Learning. (2017). Open educational resources: From commitment to action. Burnaby: COL. Retrieved from http://oasis.col.org/handle/11599/2789

Commonwealth of Learning. (2018). About the commonwealth of learning. Retrieved from https://www.col.org/about/what-commonwealth-learning

Index Mundi. (2018, January 20). Tonga demographics profile 2018. Retrieved from indexmundi.com: https://www.indexmundi.com/tonga/demographics profile.html

Kaitani, M., \& McMurray, C. (2006). Tonga. A situation analysis of children, women and youth. Fiji: UNICEF Pacific Ofiice. Retrieved from https://www.unicef.org/pacificislands/TONGAN_SITAN.pdf

Kasinathan, G., \& Ranganathan, S. (2017). Creating and repurposing OER using FOSS: A how-to guide for teachers and learners. Burnaby: Commonwealth of Learning. Retrieved from http://oasis.col.org/handle/11599/2764

Ministry of Education and Training. (2017, March 15). Tonga institute of education. Retrieved from http://www.edu.gov.to/divisions/tioe-tonga-institute-of-education

Phalachandra, B., \& Abeywardena, I. S. (2016). Open educational resources in the commonwealth 2016. Burnaby: Commonwealth of Learning. Retrieved from http://oasis.col.org/handle/11599/2441

Smulders, D. (2016). External review toolkit for odl and elearning courses. Burnaby: Commonwealth of Learning. Retrieved from http://oasis.col.org/handle/11599/2338

The Heritage Foundation. (2018). 2018 index of economic freedom. Retrieved from https://www.heritage.org/index/country/tonga

The Open University of Sri Lanka. (2017). Instructional video production for teaching and learning. Burnaby: COL. Retrieved from http://oasis.col.org/handle/11599/2748

The Tonga Institute of Higher Education. (2018). The Tonga institute of higher education. Retrieved from http://www.tihe.org

UNESCO. (2015). Education 2030: Incheon declaration and framework for action. Incheon, South Korea: Author. Retrieved from http://unesdoc.unesco.org/images/0024/002432/243278e.pdf

UNESCO. (2017). Ljubljana OER action plan 2017. Paris: UNESCO. Retrieved from https://en.unesco.org/sites/default/files/ljubljana_oer_action_plan_2017.pdf 
OER Mainstreaming in Tonga

Abeywardena, Uys, and Fifita

Athabasca

University

(c) 